\title{
Antithrombotic Activity of Milk Protein Hydrolysates by Lactic Acid Bacteria Isolated from Commercial Fermented Milks
}

\author{
Emmanuel Pérez-Escalante ${ }^{1}$, Judith Jaimez-Ordaz ${ }^{1}$, Araceli Castañeda-Ovando ${ }^{1}$, \\ Elizabeth Contreras-López ${ }^{1}$, Javier Añorve-Morga ${ }^{1}$,Luis Guillermo González-Olivares ${ }^{\mathbf{1}^{*}}$ \\ ${ }^{1}$ Universidad Autónoma del Estado de Hidalgo-Área Académica de Química-Mineral de la Reforma, Hidalgo, \\ México
}

\begin{abstract}
In the last decade, thrombosis has been one of the pathologies with high incidence creating great concern in Health Institutes all around the world. Considering this, the aim of this research was to determine the antithrombotic activity of peptides released during lactic fermentation. Reconstituted skim milk powder was fermented by Lactobacillus casei Shirota and Lactobacillus johnsonii LAl isolated from commercial fermented milks. The hydrolysis degree and proteolytic profile were analyzed by trinitrobenzenesulfonic acid spectrophotometry method and by peptide polyacrylamide electrophoresis gel separation. The milk fermented by Lactobacillus casei Shirota exhibited a higher concentration of free amino groups than that fermented by Lactobacillus johnsonii LA1. Additionally, in both fermentation systems peptides with molecular weights lower than $1.4 \mathrm{kDa}$ were observed. The highest inhibition of thrombin $(31.67 \pm 2.35 \%)$ was observed in milk fermented by Lactobacillus johnsonii LA1 at 10 hours of fermentation. Finally, no relationship was found between the antithrombotic capacity and the proteolytic profile.
\end{abstract}

Keywords: Antithrombotic activity, peptides, lactic fermentation, probiotic bacteria, commercial fermented milks

*Author for correspondence: lgonzales@uaeh.edu.mx 


\section{INTRODUCTION}

Research about protein fractions with biological activity in different foods, such as: egg, meat, fish, soy and milk, is very recent since it started at the end of the 20th century. Protein fractions conferring physiological benefits on humans were termed bioactive peptides ${ }^{1,2}$. It was found that peptides derived from milk proteins have the greatest diversity of functional characteristics ${ }^{3,4}$.

Peptidic fractions can be obtained from two different processes: using digestive enzymes such as pepsin or trypsin and using intrinsic proteases from lactic acid bacteria. This last has been the most used, obtaining a great diversity of peptide fractions with bioactive potential, because the proteolytic system of this kind of bacteria ${ }^{5,6}$.

Nowadays, lactic acid bacteria have been incorporated as starter cultures to dairy products, not only for its sensorial functions but also to improve the human health through its consumption ${ }^{7}$. Species like Lactobacillus acidophilus and Lactobacillus casei have shown some benefits to health such as antimutagenic, anticancerigen, immunomodulatory, protection against gastrointestinal pathogen bacteria and ultraviolet irradiation ${ }^{8-10}$. In the case of Lactobacillus casei Shirota is a Gram-positive probiotic with homofermentative metabolism and auxotrophy by valine and glutamic acid while Lactobacillus johnsonii LA1 also is a Gram-positive bacteria with strict anaerobic metabolism to obtain energy and it has a total dependence of exogenous aminoacids for its growth and develops ${ }^{8,11}$.

These metabolic characteristics allow that during fermentation and cold storage of commercial fermented milks, lactic acid bacteria are capable to release little fractions of proteins, which show biological activity ${ }^{12,13}$. One of the most important properties of these peptides is the antithrombotic activity ${ }^{4,6}$, which follows three different ways: platelet aggregation inhibition, inhibition of thrombin action, and fibrinolytic activity 14 .

Some peptides with antithrombotic activity are derived from the $\kappa$-casein dairy protein, in this case, the peptides are encrypted in three amino acid fractions: $\mathrm{f}(106-$ 116), $\mathrm{f}(106-113)$ and $\mathrm{f}(113-116)$, which have been named as casoplatelin ${ }^{6,15}$. All these peptides present platelet aggregation inhibition, but only $\mathrm{f}(106-116)$ present competitive inhibition on platelet fibrinogen receptor ${ }^{15}$. These characteristics allow the inclusion of these fractions in medical treatments for thrombosis, which nowadays remains to be a high incidence pathology related to human diseases all around the world ${ }^{16}$.

Antithrombotic fractions derived from milk proteins, prevent the conversion of human fibrinogen into fibrin by thrombin inhibition ${ }^{13,17}$. This conversion is responsible for providing stability to the thrombus, which keeps off normal circulation of the bloodstream and increases veins or arteries wall pressure ${ }^{18}$. Thus, the aim of this research was to determine the antithrombotic capacity of peptide fractions released during milk fermentation, by the proteolytic activity of Lactobacillus casei Shirota and Lactobacillus johnsonii LA1 isolated from commercial fermented milks.

\section{MATERIAL AND METHODS}

\section{Isolation and Propagation of Lactic Acid Bacteria}

Lactobacillus casei Shirota and Lactobacillus johnsonii LA1 were isolated from two different commercial fermented milks Yakult $^{\circledR}$ (Yakult, Mexico) and Chamyto ${ }^{\circledR}$ (Nestlé, México) following modifications proposed by Figueroa-González et al. ${ }^{19}$ to those methodology described previously by Tharmaraj and Shah ${ }^{20}$. Isolation was carried out using $10 \mathrm{~mL}$ of MRS broth (BD-Difco, Franklin Lakes, NJ-USA), 
inoculating $1 \mathrm{~mL}$ of the commercial fermented milk and incubating for 32 hours at $37^{\circ} \mathrm{C}$.

Seeding was performed on MRS agar plates to verify colonial morphology and Gram staining to verify the purity of the culture. The propagation was performed in $10 \mathrm{~mL}$ of $10 \%(\mathrm{w} / \mathrm{v})$ pasteurized milk inoculating $1 \mathrm{~mL}$ of MRS broth tube. The starter culture was prepared in a flask with $100 \mathrm{~mL}$ of $10 \%$ (w/v) pasteurized milk, inoculated with $1 \mathrm{~mL}$ of the propagation tube. Throughout the propagation, the system was incubated for 32 hours at $37^{\circ} \mathrm{C}$. The pasteurized milk solutions was made with skim milk powder (Dairy America, Fresno, CA-USA) and heated at $90^{\circ} \mathrm{C}$ for 10 minutes in an autoclave. A viable count was performed to carry out the inoculation in the fermentation systems.

\section{Fermentation}

Fermentation was carried out in $250 \mathrm{~mL}$ Erlenmeyer flasks. These contained $150 \mathrm{~mL}$ of a $10 \%(w / v)$ skim milk powder (Dairy America, Fresno, CA-USA) solution with $2 \%$ lactose (Bioxon, Mexico City-Mexico). The medium was heat treated at $90^{\circ} \mathrm{C}$ for 10 minutes. The solution was inoculated with $300 \mathrm{CFU} / \mathrm{mL}$ and fermented at $37^{\circ} \mathrm{C}$ until the medium reached a $\mathrm{pH}$ of 4.5 . The experiments were performed by triplicate and the sampling was done at five different times $\left(T_{1}, T_{2}, T_{3}, T_{4}\right.$ and $\left.T_{5}\right)$ for each fermentation system. In the fermentation with Lactobacillus casei Shirota the considered times were $0,4,10,26$ and 33 hours while with Lactobacillus johnsonii LA1 the times were $0,4,10,22$ and 26 hours. The collected samples were centrifuged at $25,0000 \mathrm{~g}$ for $10 \mathrm{~min}$ at $4^{\circ} \mathrm{C}$. The supernatants were recovered and stored in freezer for further analyses of proteolytic profile and antithrombotic capacity.

\section{Determination of the Hydrolysis Degree}

The hydrolysis degree during fermentation was calculated by the determination of free amino groups by means of the trinitrobenzenesulfonic acid (TNBS) technique proposed by Adler-Nissen ${ }^{21}$. Samples $(0.250 \mathrm{~mL})$ were mixed with $2 \mathrm{~mL}$ phosphate buffer $0.2 \mathrm{M}$ at pH 8.2 and $2 \mathrm{~mL} \mathrm{0.1 \%} \mathrm{TNBS} \mathrm{reagent} \mathrm{(Sigma-Aldrich,} \mathrm{St} \mathrm{Louis,} \mathrm{MO-}$ USA). The mixture was incubated protected from light for $60 \mathrm{~min}$ at $50^{\circ} \mathrm{C}$. The reaction was stopped using $4 \mathrm{~mL} \mathrm{HCl} 0.1 \mathrm{M}$, then the corresponding absorbance was recorded at $340 \mathrm{~nm}$. A glycine standard curve was made for determining the free amino group concentration.

\section{Peptides Separation by Electrophoresis (Tris-Tricine-SDS-PAGE)}

The method proposed by Schägger and Von Jagow ${ }^{22}$ was used considering the modifications proposed by González-Olivares et al. ${ }^{12}$. The protein concentration of the samples was analyzed with the Bradford method ${ }^{23}$ and standardized at $150 \mathrm{ppm}$. Samples were centrifuged at $25,000 \mathrm{~g}$ at $4^{\circ} \mathrm{C}$ for $10 \mathrm{~min}$ and supernatants were lyophilized. The lyophilizates were re-suspended in $100 \mu \mathrm{L}$ of Milli-Q deionized water $(18.2 \mathrm{M} \Omega \cdot \mathrm{cm})$. Electrophoresis was performed on a $16.5 \% \mathrm{~T}$ gel from a $30 \% \mathrm{~T}$ solution (acrylamide:bisacrylamide ratio 19:1 and 5\% cross-linker, Bio-Rad, Hercules, CA-USA). The gels were stained with Comassie Blue G-250 (Bio-Rad, Hercules, CAUSA) and analyzed with Image J software (IJ 1.46r, v.1.8.0_112, Bethesda, MD, USA, 2004).

\section{Determination of the Antithrombotic Capacity}


The antithrombotic activity was determined by the inhibition of fibrinogen-fibrin conversion in accordance to the method described by Zhang et al. ${ }^{24}$ with some modifications. Reactions were carried out with a double volume of all solutions respect to the reference technique. Enzymatic assays were performed in the absence of light. The calculation of the thrombin inhibitory capacity was performed according to Eq. 1:

Where:

$$
\text { Thrombin inhibition }(\%)=\left(\frac{[C-C B]-[S-S B]}{[C-C B]}\right) X 100 \quad \text { Eq. } 1
$$

CB: Control blank before incubating at $37^{\circ} \mathrm{C}$

$\mathrm{C}$ : Control after incubating at $37^{\circ} \mathrm{C}$

SB: Sample blank before incubating at $37^{\circ} \mathrm{C}$

S: Sample after incubating at $37^{\circ} \mathrm{C}$

\section{Statistical Analysis}

Results were analyzed by one-way ANOVA $(p=0.05)$ and through Tukey's contrast with the NCSS statistical software (NCSS 2007, v.0, Kaysville, UT, USA, 2007).

\section{RESULTS AND DISCUSSION}

\section{Fermentation}

During fermentation, different times to reach $\mathrm{pH} 4.5$ depending on the bacteria were observed (Table 1). In the case of L. casei Shirota, $\mathrm{pH}$ was achieved at 33 hours of fermentation, while with $L$. johnsonii LA1 it was achieved after 26 hours. A significant change from the initial $\mathrm{pH}$ value was exhibited after 4 and 10 hours in both fermentations. Also, notable differences were observed at 10 hours between fermented milks, where the process with $L$. casei Shirota achieved a pH of 6.42 while fermentation with $L$. johnsonii LA1 was of 6.35 . These results are comparable with those obtained by Solieri et al. ${ }^{25}$, where pH's over 6 were observed in UHT skim milk at first hours of fermentation.

In contrast, Østlie et al. ${ }^{26}$ reported that pH's below 6 are observed during the first eight hours of fermentation for some probiotic bacteria ( $L$. acidophilus La5, $L$. acidophilus 1748, L. johnsonii LA1, L. rhamnosus GG, L. reuteri SD 2112 and Bifidobacterium animalis BB12). However, the media used was UHT milk supplemented with tryptone as additional nitrogen source. Also, it is well known that acid production is related directly to the growth media, where the production of organic acids is faster in a supplemented than in a natural media, like milk ${ }^{27,28}$.

In another way, values of $\mathrm{pH}$ with $L$. johnsonii LA1 decreased faster than that of $L$. casei Shirota from 10 to 26 hours of fermentation (6.35 to 4.54 and 6.42 to 5.25, respectively). These results can be related to the nutritional needs of each strain, and the effectiveness to convert lactose to lactic acid. Østlie et al. ${ }^{26}$ found that L. johnsonii LA1 had a low production of lactic acid and it maintained a $\mathrm{pH}$ around 5.0 until the end of the fermentation $(48 \mathrm{~h})$ with a diminution in viable cell number. Nonetheless, in the present study, the lactose incorporated increased the carbon source concentration in the media promoting a faster acidification ( $\mathrm{pH} 4.53$ at $26 \mathrm{~h}$ ).

On the other hand the present work indicates that L. casei Shirota has a lower effectiveness to produce lactic acid under the tested conditions. Although, Zalán et al. ${ }^{27}$ found that $L$. casei Shirota exhibited the best milk acidification compared with other lactic acid bacteria like L. casei 154, L. paracasei 2750 and L. plantarum 01. The different fermentation patterns are derived of the duplication capacity of the lactic 
acid bacteria and their metabolic needs and these kind of factors are involved in the activation of the proteolytic system, which is the origin of bioactive peptides releasing 29,30 .

Table 1. Changes in $\mathrm{pH}$ and proteolysis during milk fermentation

\begin{tabular}{|c|c|c|c|c|}
\hline \multirow[b]{2}{*}{$\begin{array}{l}\text { Fermentation } \\
\text { Time }\end{array}$} & \multicolumn{2}{|c|}{$\mathrm{pH}$} & \multicolumn{2}{|c|}{ Free amino groups concentration $\left(\mu \mathrm{g} \cdot \mathrm{L}^{-1}\right)$} \\
\hline & $\begin{array}{l}\text { Lactobacillus } \\
\text { casei Shirota }\end{array}$ & $\begin{array}{c}\text { Lactobacillus } \\
\text { johnsonii LA1 }\end{array}$ & $\begin{array}{l}\text { Lactobacillus } \\
\text { casei } \text { Shirota }\end{array}$ & $\begin{array}{l}\text { Lactobacillus } \\
\text { johnsonii LA1 }\end{array}$ \\
\hline 1 & $6.72 \pm 0.00^{\mathrm{e}}$ & $6.74 \pm 0.00^{\mathrm{e}}$ & $112.67 \pm 0.58^{\mathrm{A}, \mathrm{e}}$ & $335.00 \pm 1.00^{\mathrm{B}, \mathrm{e}}$ \\
\hline 2 & $6.61 \pm 0.01^{\mathrm{d}}$ & $6.65 \pm 0.01^{\mathrm{d}}$ & $208.00 \pm 2.00^{\mathrm{A}, \mathrm{d}}$ & $372.33 \pm 2.52^{\mathrm{B}, \mathrm{d}}$ \\
\hline 3 & $6.42 \pm 0.01^{\mathrm{c}}$ & $6.35 \pm 0.02^{\mathrm{c}}$ & $389.00 \pm 7.55^{\mathrm{A}, \mathrm{c}}$ & $383.67 \pm 3.51^{\mathrm{A}, \mathrm{c}}$ \\
\hline 4 & $5.25 \pm 0.01^{\mathrm{b}}$ & $4.87 \pm 0.05^{\mathrm{b}}$ & $582.33 \pm 4.93^{\mathrm{A}, \mathrm{b}}$ & $432.33 \pm 3.21^{\mathrm{b}}$ \\
\hline 5 & $4.50 \pm 0.02^{\mathrm{a}}$ & $4.54 \pm 0.02^{\mathrm{a}}$ & $616.67 \pm 1.53^{\mathrm{a}}$ & $577.00 \pm 2.00 \mathrm{~A}, \mathrm{a}$ \\
\hline
\end{tabular}

Different lowercase letters in the same column show significant difference $(\mathrm{p}=0.05)$, while different uppercase letters show significant difference $(\mathrm{p}=0.05)$ for the fermentation hours contrastable between strains. The potentiometer used has a precision of $\pm 0.01 \mathrm{pH}$ units

\section{Determination of Free Amino Groups}

Proteolytic activity exhibited differences between both isolated microorganisms. At 4 hours of fermentation, it was observed, a less concentration of free amino groups in milk fermented by $L$. casei Shirota $\left(208 \mu \mathrm{g} \cdot \mathrm{L}^{-1}\right)$, than those in milk fermented by $L$. johnsonii LA1 (372.33 $\left.\mu \mathrm{g} \cdot \mathrm{L}^{-1}\right)$ (Table 1). These results could be explained because of the differences in the initial concentration of free amino groups in the milk solutions and the action of proteinases such as PrtP and the system for peptides transport ${ }^{30,31}$. According to Liu et al. ${ }^{32}$ some species of $L$. casei exhibit three different oligopeptides transport systems rather than one. This characteristic allows efficiency in the nitrogen obtaining, compared with those strains that have just one transport system. Thus, long chain oligopeptides could be generated by $L$. casei Shirota, which were taken instantaneously and released at the same time. For this reason, the free amino groups are not detected in the $L$. casei Shirota fermentation.

At time 3 (10 hours) of fermentation, no significant differences were observed in the concentrations of free amino groups in both fermented milks. A similar behavior was observed, in fermented milks with different lactic acid bacteria up to 12 hours of process ${ }^{33}$. This could be because bacteria followed the main proteins hydrolysis pathway for obtaining its nitrogen requirements from the oligopeptides and amino acids transport ${ }^{31,32}$.

Moreover, L. casei Shirota presented a higher proteolytic activity between time 3 and time 5, compared to the activity shown by L. johnsonii LA1. Finding at the end of the fermentation a higher concentration of amino groups in $L$. casei Shirota fermented milk $\left(616.67 \mu \mathrm{g} \cdot \mathrm{L}^{-1}\right)$ compared with fermented milk by $L$. johnsonii LA1 $\left(577.0 \mu \mathrm{g} \cdot \mathrm{L}^{-}\right.$ $\left.{ }^{1}\right)$. This increase could be related to the activation of dipeptidases and tripeptidases, specific to each proteolytic system ${ }^{32,34}$. Also, it is known that L. casei strains have higher capacity to hydrolyze small peptides producing free amino groups ${ }^{12,35}$.

\section{Peptides Separation by Tris-Tricine SDS-PAGE}

The electrophoresis analysis revealed a decrease in casein concentration and imperceptible changes in the concentration of globular proteins ( $\alpha$-lactalbumin and $\beta$ lactoglobulin) (Fig. 1 and Fig. 2). This is related to the fact, that lactic acid bacteria fulfil their nitrogen requirements mainly through caseins hydrolysis, for example in commercial fermented milks casein concentration is reduced around $50 \%{ }^{36}$. In the 
current study, no sufficient changes in the hydrolysis of casein and a wrong separation were observed in the fermentation with $L$. casei Shirota at time 2 (according the bands separated); for this reason this result is only presented in Figure 1.

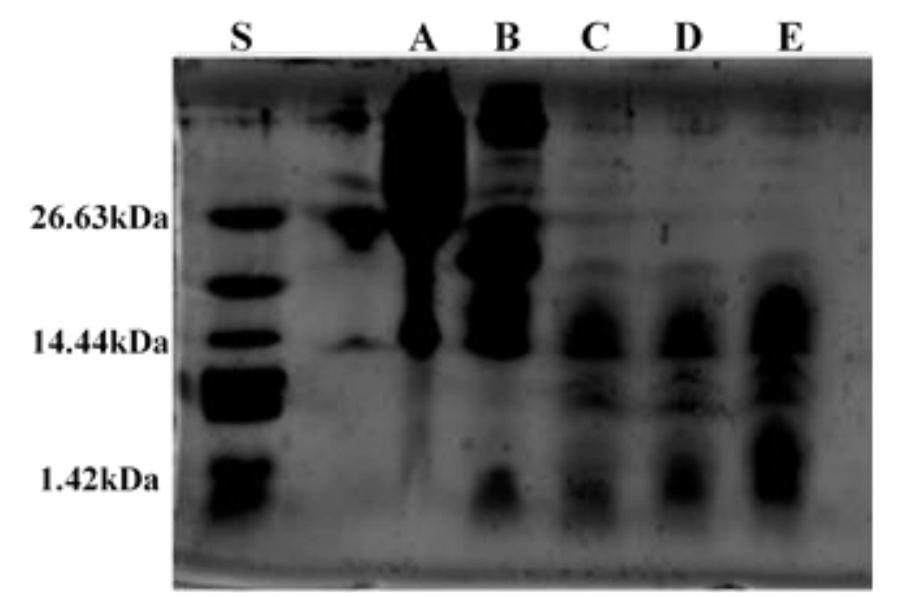

Figure 1. Peptide separation from milk fermented by Lactobacillus casei Shirota.

S: Polypeptide standard (BioRad, Hercules, CA-USA). Fermented milk at A: 4h, B: 10h, C: 26h, D: 30h and E: 33h

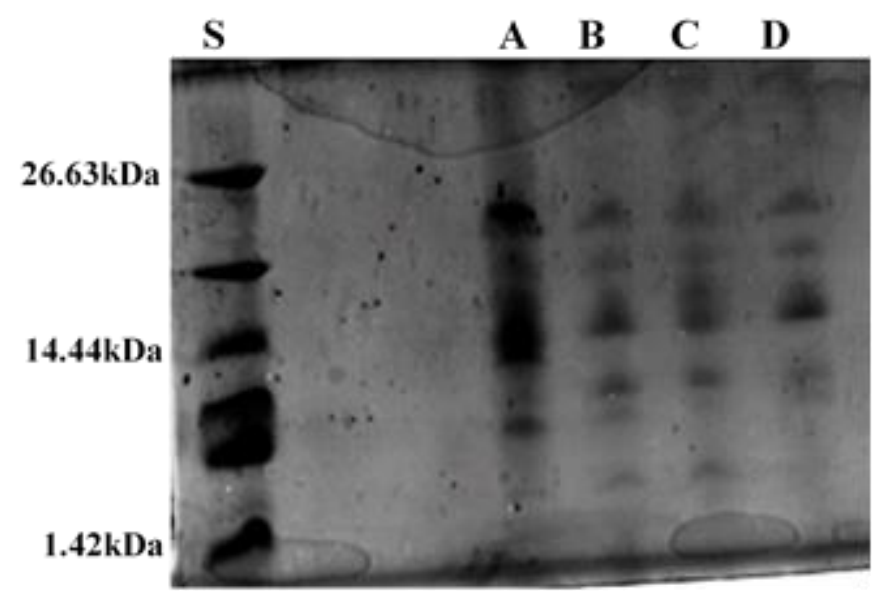

Figure 2. Peptide separation from milk fermented by Lactobacillus johnsonii LA1.

S: Polypeptide standard (BioRad, Hercules, CA-USA). Fermented milk at A: 10h, B: 22h, C: 24h and D: $26 \mathrm{~h}$

As shown in Figure 1, there is an accumulation of peptides with low molecular weight, due to superior proteolysis of $L$. casei Shirota compared with that of L. johnsonii LA1 (Fig. 2), where there was less accumulation of this kind of peptides. The final concentration results in both fermentations are coincident with those previously found in the analysis of free amino groups. Even though, through image analysis it was possible to determine peptides smaller than $1.4 \mathrm{kDa}$ in both fermentations (Fig. 1 and Fig. 2).

Moreover, it was observed different peptidic fractions of the same molecular weight during all the fermentation process. These fractions were observed between 6.2 and $6.9 \mathrm{kDa}$, in the case of milk fermented with L. casei Shirota (Fig. 1) and 7.0 and 7.6 $\mathrm{kDa}$ for milk fermented by L. johnsonii LA1 (Fig. 2). These results approached to those obtained by Rojas-Ronquillo et al. ${ }^{17}$ and by González-Olivares et al. ${ }^{12}$. Inclusively, the results demonstrate that the proteolytic system of lactic acid bacteria follows a cascade pattern to obtain all their nitrogen needs ${ }^{37}$.

The differences in the proteolytic profiles are related to the presence of some peptides between 7 and $10 \mathrm{kDa}$, which were observed only in the first hours of the process in 
milk fermented with $L$. casei Shirota while peptides in this range were exhibited during all the fermentation process with L. johnsonii LA1.

\section{Determination of Antithrombotic Capacity}

Samples for analysis of antithrombotic activity were chosen according the $\mathrm{pH}$ obtained into fermentation and electrophoresis analysis, starting in the time 3 where the $\mathrm{pH}$ observed was near to the range of the optimal proteinase activity (6.0-6.3) and the other times due to the variety of peptides showed in the hydrolysis analysis. Furthermore, it has been observed that in the first fermentation times there is no antithrombotic activity or it is not detectable ${ }^{17}$.

Peptidic fractions derived of milk fermented with L. casei Shirota showed an increasing trend in thrombin inhibition capacity until time 4 (Fig. 3). However, at the end of the fermentation (time 5), this inhibitory activity decreased to a level of $3.64 \pm 0.09 \%$, showing its highest value at time $4(20.17 \pm 2.33 \%)$. These results are consistent with those reported by Rojas-Ronquillo et al. ${ }^{17}$, where it is found a similar inhibition pattern with the same microorganism but used only bovine casein.

For samples of milk fermented by L. johnsonii LA1, the maximum antithrombotic activity $(31.67 \pm 2.35 \%)$ was obtained at time 3 and it decreased at the end of the fermentation. Also at time 3, milk inoculated with $L$. casei Shirota presented a thrombin inhibition of $10.04 \pm 0.95 \%$, although the concentration of free amino groups in this time did not showed a significant difference between the two fermentations.

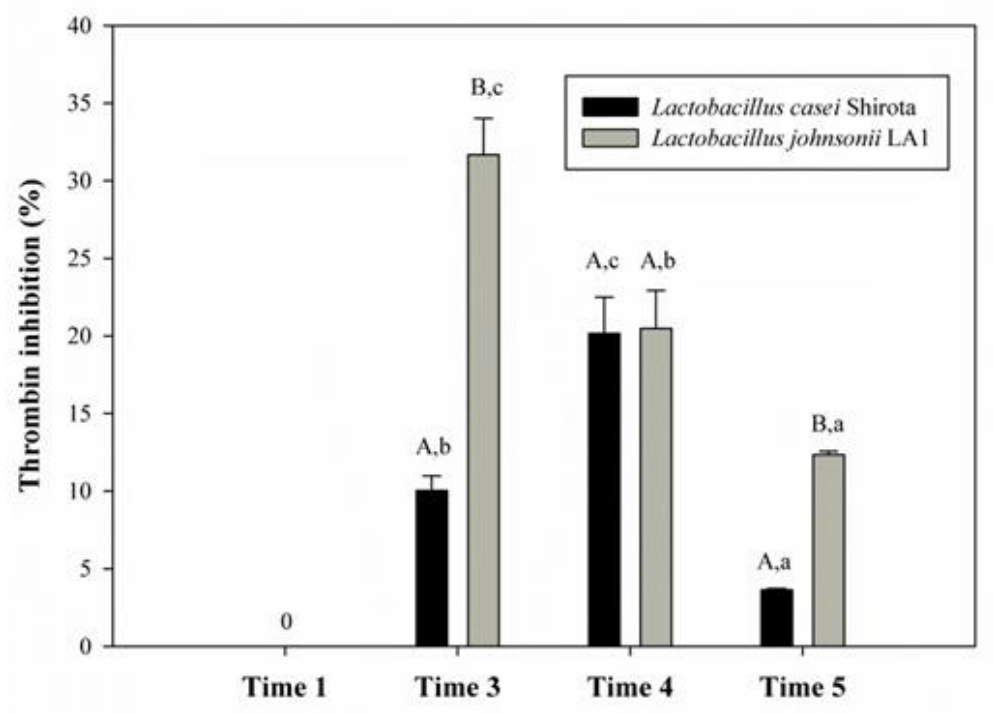

Figure 3. Thrombin inhibition produced by peptides released during milk fermentation.

Different uppercase letters show significant difference $(\mathrm{p}=0.05)$ between both fermented milks, while different lowercase letters show significant difference $(\mathrm{p}=0.05)$ in each fermented milks.

These results may be due to the auxotrophy of each microorganism as well as the specificity of its own proteolytic system ${ }^{32}$. This last was verified according to the variety of molecular weights for peptides found in this study during the electrophoretic separation, where greater variability peptides with molecular weights between 1 and 8 $\mathrm{kDa}$ were found in milk fermented with $L$. johnsonii LA1, compared to those of milk fermented with $L$. casei Shirota at time 3. It was observed that the highest thrombin inhibition is found for peptides with molecular weights in this range ${ }^{17}$. 
On the other hand, a higher thrombin inhibition $(31.67 \pm 2.35 \%)$ at less time $(10 \mathrm{~h})$ was observed in this study in the fermentation with $L$. johnsonii LA1, than that reported by El-Fattah et al. ${ }^{38}$. While, in the fermentation realized with $L$. casei Shirota, a similar thrombin inhibition activity was reached but it required of $26 \mathrm{~h}$ instead of $16 \mathrm{~h}$ which was reported in the fermentation of milk by Lactobacillus casei B-1922 ${ }^{38}$.

Finally, although molecular weight of the peptides was similar in both fermentations at the end of the process it was shown different antithrombotic capacity. In fact, it might be related with the affinity of the thrombin active site to bonds between arginine and glycine (Arg-Gly) ${ }^{39}$. In addition, Chabance et al. ${ }^{40}$ and Rojas-Ronquillo et al. ${ }^{17}$ have reported that rich sequences in proline, phenylalanine or isoleucine exhibit high thrombin inhibition. Also, Mehta et al. ${ }^{41}$ reported that the presences of acid, hydrophobic and aromatic amino acids are essential for the thrombin recognition. These kinds of sequences or amino acids could be obtained during fermentation process affecting its antithrombotic capacity.

\section{CONCLUSION}

Under the tested conditions, lactic acid bacteria isolated from commercial fermented milks showed proteolytic capacity and accumulation of low molecular weight peptides with antithrombotic activity during fermentation process of milk. However, this capacity is not dependent of the free amino groups concentration and differs for each fermentation system, and it is directly related to the specificity of the proteolytic system of each lactic acid bacteria. Also, despite both studied strains have a high potential to produce thrombin inhibitors peptides, using milk as media, L. johnsonii LA1 presented the better characteristics to produce antitrombotic peptides.

\section{ACKNOWLEDGEMENTS}

The authors appreciate the support of Consejo Nacional de Ciencia y Tecnología (CONACyT) for the resources of the basic science project 2014 number 241333

\section{REFERENCES}

1. Daliri E, Oh D, Lee B. Bioactive Peptides. Foods. 2017; 6(5): 32.

2. Li-Chan ECY. Bioactive peptides and protein hydrolysates: Research trends and challenges for application as nutraceuticals and functional food ingredients. Curr. Opin. Food Sci. 2015; 1: 28-37.

3. Sánchez-Rivera L, Martínez-Maqueda D, Cruz-Huerta E, Miralles B, Recio I. Peptidomics for discovery, bioavailability and monitoring of dairy bioactive peptides. Food Res. Int. 2014; 63: 170-181.

4. Nongonierma AB, FitzGerald RJ. The scientific evidence for the role of milk proteinderived bioactive peptides in humans: A Review. J. Funct. Foods. 2015; 17: 640-656.

5. Hafeez Z, Cakir-Kiefer C, Roux E, Perrin C, Miclo L, Dary-Mourot A. Strategies of producing bioactive peptides from milk proteins to functionalize fermented milk products. Food Res. Int. 2014; 63: 71-80.

6. Pessione E, Cirrincione S. Bioactive molecules released in food by lactic acid bacteria: Encrypted peptides and biogenic amines. Front. Microbiol. 2016; 7: 1-19.

7. Giraffa G, Chanishvili N, Widyastuti Y. Importance of lactobacilli in food and feed biotechnology. Res Microbiol. 2010; 161(6): 480-487.

8. Miyazaki K, Matsuzaki T. Health properties of milk fermented with Lactobacillus casei strain Shirota (LcS). In: Farnworth ER, editor. Handbook of Fermented Functional Foods. Second Edition. Boca Raton: CRC Press; 2008. p. 165-208.

9. Neish AS. Probiotics of the Acidophilus Group: Lactobacillus acidophilus, delbrueckii subsp. bulgaricus and johnsonii. In: Floch MH, Ringel Y, Walker WA, editors. The Microbiota 
in Gastrointestinal Pathophysiology: Implication for Human Health, Prebiotics, Probiotics, and Dysbiosis. London: Academic Press; 2017. p. 71-78.

10. Shah NP. Functional cultures and health benefits. Int. Dairy J. 2007; 17(11): 1262-1277.

11. Pridmore RD, Berger B, Desiere F, Vilanova D, Barretto C, Pittet AC, et al. The genome sequence of the probiotic intestinal bacterium Lactobacillus johnsonii NCC 533. Proc. Natl. Acad. Sci. U.S.A. 2004; 101(8): 2512-2517.

12. González-Olivares LG, Jiménez-Guzmán J, Cruz-Guerrero A, Rodríguez-Serrano G, Gómez-Ruiz L, García-Garibay M. Liberación de péptidos bioactivos por bacterias lácticas en Leches fermentadas comerciales. [Bioactive peptides released by lactic acid bacteria in commercial fermented milks]. Rev. Mex. Ing. Quim. 2011; 10(2): 179-188.

13. Domínguez-González KN, Cruz-Guerrero A, González-Márquez H, Gómez-Ruiz L, García-Garibay M, Jiménez-Guzmán J, et al. Antihypertensive and antithrombotic activities of a commercial fermented milk product made with Lactobacillus casei Shirota and Streptococcus thermophilus. Int J Dairy Technol. 2014; 67(3): 358-364.

14. Greineder CF, Howard MD, Carnemolla R, Cines DB, Muzykantov VR. Advanced drug delivery systems for antithrombotic agents. Blood. 2013; 122(9): 1565-1575.

15. Fiat M, Migliore-Samour D, Jollès P, Drouet L, Bal dit Sollier C, Caen J. Biologically active peptides from milk proteins with emphasis on two examples concerning antithrombotic and immunomodulating activities. J. Dairy Sci. 1993; 76(1): 301-310.

16. Wendelboe AM, Raskob GE. Global Burden of Thrombosis. Circ. Res. 2016; 118(9): 1340-1347.

17. Rojas-Ronquillo R, Cruz-Guerrero A, Flores-Nájera A, Rodríguez-Serrano G, GómezRuiz L, Reyes-Grajeda JP, et al. Antithrombotic and angiotensin-converting enzyme inhibitory properties of peptides released from bovine casein by Lactobacillus casei Shirota. Int. Dairy J. 2012; 26(2): 147-154

18. La Corte AC, Philippou H, Ariëns RA. Role of fibrin structure in thrombosis and vascular disease. Adv Protein Chem Str. 2011; 83:75-127.

19. Figueroa-González I, Hernández-Sánchez H, Rodrıguez-Serrano G, Gómez-Ruiz L, Garcia-Garibay M, Cruz-Guerrero A. Antimicrobial effect of Lactobacillus casei strain Shirota co-cultivated with Escherichia coli UAM0403. Rev. Mex. Ing. Quim. 2010; 9(1): 11-16.

20. Tharmaraj N, Shah NP. Selective enumeration of Lactobacillus delbrueckii ssp. bulgaricus, Streptococcus thermophilus, Lactobacillus acidophilus, bifidobacteria, Lactobacillus casei, Lactobacillus rhamnosus, and Propionibacteria. J. Dairy Sci. 2003; 86(7): 2288-2296.

21. Adler-Nissen J. Determination of the Degree of Hydrolysis of Food Protein Hydrolysates by Trinitrobenzenesulfonic. J. Agric. Food Chem. 1979; 27(6): 1256-1262.

22. Schägger H, Von Jagow G. Tricine-sodium dodecyl sulfate-polyacrylamide gel electrophoresis for the separation of proteins in the range from 1 to $100 \mathrm{kDa}$. Anal. Biochem. 1987; 166(2): 368-379.

23. Kruger NJ. The Bradford Method for Protein Quantitation. In: Walker JM, editor. Methods in Molecular Biology. Totowa: Humana Press; 1994. p. 9-15.

24. Zhang SB, Wang Z, Xu SY. Antioxidant and antithrombotic activities of rapeseed peptides. J. Am. Oil Chem. Soc. 2008; 85(6): 521-527.

25. Solieri L, Rutella GS, Tagliazucchi D. Impact of non-starter lactobacilli on release of peptides with angiotensin-converting enzyme inhibitory and antioxidant activities during bovine milk fermentation. Food Microbiol. 2015; 51: 108-116.

26. Østlie HM, Treimo J, Narvhus JA. Effect of temperature on growth and metabolism of probiotic bacteria in milk. Int. Dairy J. 2005; 15(10): 989-997.

27. Zalán Z, Hudáček J, Štětina J, Chumchalová J, Halász A. Production of organic acids by Lactobacillus strains in three different media. Eur. Food Res. Technol. 2010; 230(3): 395-404.

28. Widyastuti YR, Febrisiantosa A. The Role of Lactic Acid Bacteria in Milk Fermentation. Food Nutr. Sci. 2014; 5(4): 435-442.

29. Law J, Haandrikman A. Proteolytic enzymes of lactic acid bacteria. Int. Dairy J. 1997; 7(1): 1-11.

30. Savijoki K, Ingmer H, Varmanen P. Proteolytic systems of lactic acid bacteria. Appl Microbiol Biot. 2006; 71(4): 394-406.

31. Kunji ER, Mierau I, Hagting A, Poolman B, Konings WN. The proteolytic systems of lactic acid bacteria. A Van Leeuw J Microb.1996; 70: 187-221. 
32. Liu M, Bayjanov JR, Renckens B, Nauta A, Siezen RJ. The proteolytic system of lactic acid bacteria revisited: a genomic comparison. BMC Genomics. 2010:11(1): 36.

33. Hati S, Patel N, Mandal S. Comparative Growth Behaviour and Biofunctionality of Lactic Acid Bacteria During Fermentation of Soy Milk and Bovine Milk. Probiotics Antimicro. 2017; $1-7$.

34. Requena T, Pelaez C, Fox PF. Peptidase and proteinase activity of Lactococcus lactis, Lactobacillus casei and Lactobacillus plantarum. Z Lebensm Unters F A. 1993; 196(4): 351355.

35. Arora G, Lee BH. Comparative studies on peptidases of Lactobacillus casei subspecies. J. Dairy Sci. 1990; 73(2): 274-279.

36. González-Olivares, LG, Añorve-Morga J, Castañeda-Ovando A, Contreras-López E, Jaimez-Ordaz J. Peptide separation of commercial fermented milk during refrigerated storage. Food Sci Tech-Brazil. 2014; 34(4): 674-679.

37. Pritchard GG, Coolbear T. The physiology and biochemistry of the proteolytic system in lactic acid bacteria. FEMS Microbiol. Rev. 1993; 12: 179-206.

38. El-Fattah AA, Sakr S, El-Dieb SM, Elkashef, H. Biological activities of lactobacilli relevant to cardiovascular health in skim milk. Food Sci Biotechnol. 2017; 26(6): 1613-1623.

39. Bode W. Structure and interaction modes of thrombin. Blood Cell Mol Dis. 2006; 36(2): 122-130.

40. Chabance B, Jollès P, Izquierdo C, Mazoyer E, Francoual C, Drouet L, et al. Characterization of an antithrombotic peptide from $\alpha$-casein in newborn plasma after milk ingestion. Br. J. Nutr. 1995; 73(4): 583-590.

41. Mehta AY, Jin Y, Desai UR. An update on recent patents on thrombin inhibitors (20102013). Expert Opin Ther Pat. 2014; 24(1): 47-67. 